\title{
Combustion Ash From Tomato Stem and Leaf Pellets as a Fertilizer
}

\author{
Hiromi Ikeura ${ }^{1}$, Kanami Sato $^{2}$, Tatsuya Miyashita ${ }^{3} \&$ Takahiro Inakuma $^{3}$ \\ ${ }^{1}$ Organization for the Strategic Coordination of Research and Intellectual Properties, 1-1-1, Higashimita, \\ Tama-ku, Kawasaki, Kanagawa, Japan \\ ${ }^{2}$ Graduate School of Agriculture, Meiji University, 1-1-1, Higashimita, Tama-ku, Kawasaki, Kanagawa, Japan \\ ${ }^{3}$ Research Institute, KAGOME Co., LTD, 17 Nishifuji, Nasushiobara, Tochigi, Japan \\ Correspondence: Hiromi Ikeura, Organization for the Strategic Coordination of Research and Intellectual \\ Properties, 1-1-1, Higashimita, Tama-ku, Kawasaki, Kanagawa 214-8571, Japan. Tel: 81-44-934-7148. E-mail: \\ hikeura@meiji.ac.jp
}

Received: April 10, 2014 Accepted: May 7, 2014 Online Published: May 9, 2014

doi:10.5539/jsd.v7n3p78 URL: http://dx.doi.org/10.5539/jsd.v7n3p78

\begin{abstract}
In this study, we aimed to the pelletizing and utilizing of tomato stems and leaves as an energy source, and analyzed inorganic compounds ( $, \mathrm{P}, \mathrm{K}, \mathrm{Ca}, \mathrm{Mg}, \mathrm{Fe}$ and $\mathrm{Si}$ ) of the combustion ash of $20 \%$ tomato pellets, and wood pellets. Amount of N, P, K, Ca, Mg, Fe and Si of $20 \%$ tomato pellets were $0.06 \mathrm{~g} / \mathrm{kg}, 5.06 \mathrm{~g} / \mathrm{kg}, 42.92$ $\mathrm{g} / \mathrm{kg}, 37.66 \mathrm{~g} / \mathrm{kg}, 5.08 \mathrm{~g} / \mathrm{kg}, 0.15 \mathrm{~g} / \mathrm{kg}$ and $2.22 \mathrm{~kg} / \mathrm{kg}$, respectively. The $\mathrm{P}, \mathrm{K}, \mathrm{Ca}$ and $\mathrm{Mg}$ contents of $20 \%$ tomato pellets was higher than combustion ash of wood pellets, $1.27 \mathrm{mg} / \mathrm{kg}, 28.57 \mathrm{mg} / \mathrm{kg}, 33.79 \mathrm{mg} / \mathrm{kg}$ and 4.42 $\mathrm{mg} / \mathrm{kg}$, respectively. Furthermore, N, Fe and Si contents of combustion ash of $20 \%$ tomato pellets was lower than combustion ash of wood pellets. Therefore, we suggested that combustion ash of tomato stems and leaves pellets could be utilized by mixed nitrogen fertilizer or soil of over-nitrogen.
\end{abstract}

Keywords: fertilizer, combustion ash, biomass, pellet, waste of agriculture

\section{Introduction}

The issue of global warming has recently assumed serious proportions worldwide, creating a societal demand for the use of biomass energy from recycled sources. Thus, the development of renewable biomass has become highly important. Processes for producing biofuel pellets for both domestic and industrial uses have recently attracted increased attention. The production of such pellets has grown rapidly in Europe, North America, and China in the last few years (Peksa-Blauchard et al., 2007; Samuelsson et al., 2009).

In agriculture, most of the leaves, stems, and roots produced after crop harvests are disposed of as general waste (Kulcu \& Taldiz, 2004). The tomatoes leaves and stems waste, is the most widely produced vegetable in the world and is a major vegetable in Japan, amount to approximately 7 million tons per year; this weight is the same as that of the harvested fruits and represents a greater volume (Kozai, 2009). Although agricultural wastes are partly composted, most are mixed into soil and disposed of as industrial wastes by waste disposal services. However, agricultural wastes, as well as industrial by-products, are possible materials for biofuel pellet production (Gill et al., 2010).

Previous studies have examined the potential of olive plants and grape seeds (Gonzalez et al., 2004; Gill et al., 2010), which are disposed of as general wastes in northern Europe, as well as that of bamboo (Sakuma, 2007) and marijuana (Akahoshi et al., 2007) in Japan, for pelletization. In addition, Sato (2012) found that agricultural wastes may produce promising pellets, by combusting pellets from a mixture of $80 \%$ wood and $20 \%$ tomato stems and leaves. Moreover, tomato absorbs various fertilizers during its growth process and may thus contain many inorganic components (Sato et al., 2012). Therefore, we hypothesized that tomato pellet combustion ash would serve as a better fertilizer than wood pellet combustion ash.

Biomass is widely used as an alternative to fossil fuels, and the ash remaining after the combustion of wood biomass has been used as fertilizer. Uchiyama et al. (2001) reported that the combustion ash from the burning of poultry manure in a biomass boiler may be used as a fertilizer, whereas Tani (2009) investigated the use of the ash produced after the combustion of paper and pulp. In addition, the combustion ash from wood pellets used as fuel has been employed as a fertilizer (Takahashi et al., 2008). If the $\mathrm{K}$ and $\mathrm{Ca}$ contents in the combustion ash of 
wood pellets are high, and the contents and elutions of heavy metals are at the upper limits allowed for sludge manure or the standard levels of special fertilizer, the application of the ash is not hazardous to plants (Orihashi et al., 2011). Incidentally, toxic compounds included in industrial waste was set upper limit for using as fertilizer. Upper limit of heavy metal, $\mathrm{As}, \mathrm{Cd}, \mathrm{Hg}, \mathrm{Ni}, \mathrm{Cr}$ and $\mathrm{Pb}$, are 50, 5, 2, 300, 500 and $100 \mathrm{ppm}$, and that of organic phosphorus was $1 \mathrm{ppm}$. In this study, we aimed to pelletize and utilize tomato stems and leaves as an energy

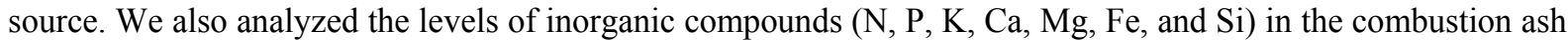
of pellets from a mixture of $80 \%$ wood and $20 \%$ tomato stems and leaves, as well as those in ash from entirely wood pellets.

\section{Materials and Methods}

\subsection{Materials and Sample Preparation}

Tomato leaves and stems were obtained from the cultivar "Round" cultivated on a contract farm at the Research Institute, KAGOME Co., LTD. Cedar chips were obtained from Tokyopellet Co., Ltd. (Tokyo, Japan). Moisture content of tomato leaves and stems was about $90 \%$. All materials were cut about 3-5 cm, dried completely for 3 days at $80{ }^{\circ} \mathrm{C}$ using a ventilating dryer (FC-2000; AS ONE Corporation, Osaka, Japan), crushed to $10 \mathrm{~mm}$ using a crusher (MF10, IKA ${ }^{\circledR}$ Japan K.K., Nara, Japan), and then prepared to a moisture content of $11 \%$ by adding distilled water. The materials were then pelletized using a pelletizer (EDRF-075B small pelletizer; Earth Engineering Corporation, Ishikawa, Japan). The moisture contents of the pellets were determined using a digital moisture measuring system (SHIMADU MOC 120H; Shimadzu Co., Kyoto, Japan). The results of the ultimate and industrial analyses of the tomato and wood pellets are shown in Table 1. "Wood pellets" are those pelletized from cedar chips, "tomato pellets are those pelletized from tomato leaves and stems, and " $20 \%$ tomato pellets" are those pelletized from $80 \%$ wood and $20 \%$ tomato stems and leaves.

\subsection{Ultimate and Industrial Analyses of Tomato and Wood Pellets}

Ultimate and industrial analysis of tomato and wood pellets were conducted according to wood pellet quality standard instituted by Japan Wood Pellet Association. Percentage of C, H, N, S were analysed according to JIS Z7302-1, 7302-7, and 7302-8, lower heating value (LHV) and ash content were measured according to JIS Z7302-1, 7302-2 and 7302-4 (Japan Wood Pellet Association, 2011).

Table 1. Ultimate and industrial analyses of tomato and wood pellets

\begin{tabular}{|c|c|c|c|c|c|c|c|}
\hline & \multicolumn{4}{|c|}{ Ultımate analy sis (\%) } & \multicolumn{2}{|c|}{ Industrial analy sis (\%) } & Lower heating value \\
\hline & $\mathrm{C}$ & $\mathrm{H}$ & $\mathrm{N}$ & $\mathrm{S}$ & Moisture percentage & Ash percentage & $(\mathrm{MJ} / \mathrm{kg})$ \\
\hline $20 \%$ tomato pellets & 41.2 & 2.1 & 5.1 & 0.4 & 11.8 & 13 & 14.8 \\
\hline wood pellets & 46.5 & 6.8 & 1.9 & 0.1 & 7.7 & 0.5 & 17.1 \\
\hline
\end{tabular}

\subsection{Inorganic Analysis}

$0.5 \mathrm{~g}$ of pellet or $0.25 \mathrm{~g}$ of combustion ash milled by mortar were decomposed according to wet ashing method and prepared constant volume $(100 \mathrm{~mL})$. N was analyzed by semimicro-Kjeldahl method (Goh, 1972), P by molybdenum yellow method (Basson et al., 1981), and Fe by the phenanthroline method (Fadrus \& Malý, 1975). Si by molybdenum method (Woods \& Mellon, 1941), K, Ca, and Mg were analyzed with an atomic absorption photometer (AA-7000, Shimadzu Co. Ltd., Kyoto, Japan). The analysis was performed in triplicates.

\subsection{Statistical Analysis}

Data are shown as mean values \pm standard error, and was analyzed ANOVA method and performed using Tukey-Kramer test, again with a significance level of $\mathrm{P}<0.05$.

\section{Results}

Ultimate and industrial analyses of tomato and wood pellets is shown in Table 1. Moisture, ash percentage and LHV of $20 \%$ tomato pellet were lower than those of wood pellet. Percentage of N and S were greater than those of wood pellets.

The amounts of the combustion ash and their inorganic components ( $\mathrm{N}, \mathrm{P}, \mathrm{K}, \mathrm{Ca}, \mathrm{Mg}, \mathrm{Fe}$, and $\mathrm{Si}$ ) per $1 \mathrm{~kg}$ of pellets are shown in Table 2. The amounts of combustion ash for the wood and $20 \%$ tomato pellets were $2.8 \mathrm{~g} / \mathrm{kg}$ and $25.3 \mathrm{~g} / \mathrm{kg}$, respectively, with the $20 \%$ tomato pellets producing approximately 9 times more ash than the wood pellets. The N, P, K, Ca, Mg, Fe and Si contents in the $20 \%$ tomato pellets were $0.06 \mathrm{~g} / \mathrm{kg}, 5.06 \mathrm{~g} / \mathrm{kg}$, $42.92 \mathrm{~g} / \mathrm{kg}, 37.66 \mathrm{~g} / \mathrm{kg}, 5.08 \mathrm{~g} / \mathrm{kg}, 0.15 \mathrm{~g} / \mathrm{kg}$ and $2.22 \mathrm{~g} / \mathrm{kg}$, respectively, whereas those in the wood pellets were 
$0.14 \mathrm{~g} / \mathrm{kg}, 1.27 \mathrm{~g} / \mathrm{kg}, 28.57 \mathrm{~g} / \mathrm{kg}, 33.79 \mathrm{~g} / \mathrm{kg}, 4.42 \mathrm{~g} / \mathrm{kg}, 0.83 \mathrm{~g} / \mathrm{kg}$ and $5.50 \mathrm{~g} / \mathrm{kg}$, respectively. These results demonstrated that the $\mathrm{P}, \mathrm{K}, \mathrm{Ca}$ and $\mathrm{Mg}$ contents in the combustion ash of the $20 \%$ tomato pellets were significantly higher than those in the ash of the wood pellets. The Fe and Si contents in the combustion ash of the $20 \%$ tomato pellets were $0.15 \mathrm{~g} / \mathrm{kg}$ and $2.22 \mathrm{~g} / \mathrm{kg}$, respectively, whereas those in the ash of the wood pellets were $0.83 \mathrm{~g} / \mathrm{kg}$ and $5.50 \mathrm{~g} / \mathrm{kg}$, respectively.

Table 2. Amount of combustion ash and contents of inorganic components in combustion ash per $1 \mathrm{~kg}$ of pellets

\begin{tabular}{|c|c|c|c|c|c|c|c|c|c|c|}
\hline \multirow[b]{3}{*}{ Combustion ash of tomato pellets } & \multirow{2}{*}{\multicolumn{2}{|c|}{$\begin{array}{c}\text { Amount of ash } \\
(\mathrm{g} / \mathrm{kg} \pm \mathrm{SD})\end{array}$}} & \multicolumn{8}{|c|}{ Inorganic contents $(\mathrm{g} / \mathrm{kg} \pm \mathrm{SD})$} \\
\hline & & & \multicolumn{3}{|c|}{$\mathrm{N}$} & \multicolumn{3}{|c|}{$\mathrm{P}$} & \multicolumn{2}{|r|}{$\mathrm{K}$} \\
\hline & $0.00 \pm 0.00^{\mathrm{z}}$ & & 0.37 & \pm 0.03 & $\mathrm{a}$ & 5.16 & \pm 0.02 & $\bar{a}$ & 40.49 & $\pm 1.30 \quad \mathrm{a}$ \\
\hline Combustion ash of $20 \%$ tomato pellets & $25.30 \pm 1.68$ & $a^{y}$ & 0.06 & \pm 0.01 & $\mathrm{~b}$ & 5.06 & \pm 0.11 & $\mathrm{a}$ & 42.92 & \pm 2.84 a \\
\hline \multirow[t]{3}{*}{ Combustion of wood pellets } & $2.77 \pm 0.09$ & $\mathrm{~b}$ & 0.14 & \pm 0.02 & $\mathrm{c}$ & 1.27 & \pm 0.17 & $\mathrm{~b}$ & 28.57 & $\pm 3.00 \mathrm{~b}$ \\
\hline & \multicolumn{10}{|c|}{ Inorganic contents $(\mathrm{g} / \mathrm{kg} \pm \mathrm{SD})$} \\
\hline & $\mathrm{Ca}$ & & & $\mathrm{Mg}$ & & & $\mathrm{Fe}$ & & & $\mathrm{Si}$ \\
\hline Combustion ash of tomato pellets & $37.53 \pm 1.77$ & $\mathrm{a}$ & 5.50 & \pm 0.47 & $\mathrm{a}$ & 0.29 & \pm 0.04 & $\mathrm{a}$ & 2.70 & $\pm 0.81 \quad \mathrm{a}$ \\
\hline Combustion ash of $20 \%$ tomato pellets & $37.66 \pm 1.26$ & $\mathrm{a}$ & 5.08 & \pm 0.53 & $\mathrm{a}$ & 0.15 & \pm 0.06 & $\mathrm{~b}$ & 2.22 & $\pm 0.68 \mathrm{a}$ \\
\hline Combustion of wood pellets & $33.79 \pm 0.15$ & $\mathrm{~b}$ & 4.42 & \pm 0.53 & $\mathrm{~b}$ & 0.83 & \pm 0.23 & $\mathrm{c}$ & 5.50 & $\pm 0.82 \mathrm{~b}$ \\
\hline
\end{tabular}

\section{Discussion}

Ultimate and industrial analysis value, and LHV are not reached the wood pellet quality standard, but Sato et al. (2012) suggested that tomato pellets may be utilized as an energy source.

$\mathrm{Si}$ content in combustion ash of the wood pellets was lower than that of $20 \%$ tomato pellets. High levels of Si in the soil can also increase its level in pellets due to the attachment of soil particles during forest growth and storage, and the combustion of these bulk pellets may form solid lumps known as clinker and slag. Clinker causes decreased combustion efficiency and corrodes burners (Carl et al., 2008; Ohman et al., 2004). Ohman et al. (2004) reported that the Si contents in pellets that were pelletized immediately after harvest and six months after cutting, were $0.8 \%$ and $4.0 \%$, respectively. The Si contents in the latter pellets were elevated due to the attachment of soil particles, and the amount of slug formation also increased due to the increase in Si. Thus, if tomato material is mixed with wood in the pellets, it is predicted that the corrosion of the burner will decrease.

The results suggested that the combustion ash of $20 \%$ tomato pellets may serve as an efficient fertilizer for vegetable cultivation, as the $\mathrm{P}, \mathrm{K}, \mathrm{Ca}$ and $\mathrm{Mg}$ contents in the combustion ash of these pellets were greater than those of ash from the wood pellets. Although the Fe content in the combustion ash of the $20 \%$ tomato pellets was the same as that in the ash of the wood pellets, trace amounts of Fe and $\mathrm{Si}$ are sufficient in vegetable cultivation. The $\mathrm{P}, \mathrm{K}, \mathrm{Ca}$, and $\mathrm{Mg}$ contents of poultry manure ash, as well as its amount, have all been reported to be greater than those of wood pellet ash; the alkalinity of this combustion ash may have a corrective effect on the soil $\mathrm{pH}$ in acidic soil, and combustion ash may be used as compost (except on acidic soil) after a neutralization treatment with waste sulfuric acid (Uchiyama et al., 2001). Additionally, the combustion ash of pulp has been reported as alkaline and containing high levels of $\mathrm{Ca}$; it may therefore be used as a lime fertilizer and soil improvement agent (Tani, 2009). The $20 \%$ tomato pellets produced a great large amount of combustion ash, and the inorganic contents of this combustion ash were greater than those in the ash of the wood pellets. The results indicate that these combustion ashes are suitable for use in acidic soil, as is the combustion ash of poultry manure, or for use in normal soils after neutralization treatment.

$\mathrm{N}, \mathrm{P}$, and $\mathrm{K}$ are the three major nutrients of fertilizer and play major roles in protein synthesis and energy metabolism (Watanabe, 2010). The $\mathrm{N}$ content in the combustion ash of the $20 \%$ tomato pellets was $10.6 \mathrm{mg} / \mathrm{kg}$, which represents a trace amount, and $\mathrm{N}$ must therefore be supplemented when using this combustion ash as a fertilizer. Therefore, the combustion ash of $20 \%$ tomato pellets may be used efficiently when mixed with $\mathrm{N}$ fertilizer or applied to soil with excess $\mathrm{N}$.

\section{Conclusion}

We aimed to the pelletizing and utilizing of tomato stems and leaves as an energy source, and analyzed inorganic compounds (N, P, K, Ca, Mg, Fe and $\mathrm{Si}$ ) of the combustion ash of $20 \%$ tomato pellets, and wood pellets. The P, $\mathrm{K}, \mathrm{Ca}$ and $\mathrm{Mg}$ contents of $20 \%$ tomato pellets was higher than combustion ash of wood pellets. N, Fe and $\mathrm{Si}$ 
contents of combustion ash of $20 \%$ tomato pellets was lower than combustion ash of wood pellets. Therefore, we suggested that combustion ash of tomato stems and leaves pellets could be utilized by mixed nitrogen fertilizer or soil of over-nitrogen. Future studies should investigate the effects of using combustion ash as an alternative fertilizer on plant growth.

\section{Acknowledgments}

We would like to thank Tetsuya Kawajiri of Tokyopellet Co., Ltd for providing the samples.

We would like to express the deepest appreciation to ex-Professor Yasuyoshi Hayata with for providing us this precious study opportunity.

\section{References}

Akahoshi, Y., Kitami, O., Ishiyama, T., Endo, R., \& Funayama, S. (2009). Study on pellet fuel for the effective utilization of resource crop hemp. Journal of the Japan Institute of Energy, 88, 900-905. http://dx.doi.org/10.3775/jie.88.900

Basson, W. D., Van Staden, J. F., \& Cattin, P. M. (1981). Determination of phosphorus $\left(\mathrm{P}_{2} \mathrm{O}_{5}\right)$ as molybdovanadophosphoric acid in phosphate rock with a flow-injection procedure. Fresenius' Zeitschrift für analytische Chemie, 307, 373-377. http://dx.doi.org/10.1007/BF00480116

Carl, G., Marcus, O., Erica, L., Dan, B., Rainer, B., \& Jan, B. (2008). Slagging Characteristics during Residential Combustion of Biomass Pellets. Energy \& Fuels, 22, 3536-3543. http://dx.doi.org/10.1021/ef800087x

Fadrus, H., \& Malý, J. (1975). Suppression of iron (III) interference in the determination of iron (II) in water by the 1,10-phenanthroline method. Analyst, 100, 549-554. http://dx.doi.org/10.1039/AN9750000549

Gill, M. V., Oulego, P., Casal, M. D., Pevida, C., Pis, J. J., \& Rubiera, F. (2010). Mechanical durability and combustion characteristics of pellets from biomass blends. Bioresource Technology, 101, 8859-8867. http://dx.doi.org/10.1016/j.biortech.2010.06.062

Goh, K. M. (1972). Comparison and Evaluation of Methods for Including Nitrate in the Total Nitrogen Determination of Soils. Journal of the Science of Food and Agriculture, 23, 275-284. http://dx.doi.org/10.1002/jsfa.2740230303

Gonzalez, J. F., Gonzalez, C. M., Ramiro, A., Gonzalez, J., Sabio, E., Ganan, J., \& Rodriguez, A. (2004). Combustion optimisation of biomass residue pellets for domestic heating with a mural boiler. Biomass and Bioenergy, 27, 145-154. http://dx.doi.org/10.1016/j.biombioe.2004.01.004

Japann Wood Pellet Association. (2011). Wood pellet quality standard. Retrieved from http://www.w-pellet.org/index $2 . h t m l$

Kozai, T. (2009). Taiyokougatashokubutukojyo (p. 9). Tokyo: Ohmsha.

Kulcu, R., \& Taldiz, O. (2004). Determination of aeration rate and kinetics of composting some agricultural wastes. Bioresource Technology, 93, 49-57. http://dx.doi.org/10.1016/j.biortech.2003.10.007

Ohman, M., Boman, C., Hedman, H., Nordin, A., \& Bostrom, D. (2004). Slagging tendencies of wood pellet ash during combustion in residential pellet burners. Biomass and Bioenergy, 27, 585-596. http://dx.doi.org/10.1016/j.biombioe.2003.08.016

Orihashi, K., Yamada, T., Takahashi, T., Tashiro, N., \& Koga, S. (2011). Basic knowledge of woody biomass combustion ash for reductive forest land. Bulliten of Kyushu University Forest, 92, 13-18.

Peksa-Blauchard, M., Dolzan, P., Grassi, A., Heinimö, J., Junginger, M., Ranta, T., \& Walter, A. (2007). Global Wood Pellets Markets and Industry: Policy drivers. Market Status and Raw Material Potential. IEA Bioenergy Task 40.

Sakuma, M. (2007). Development of biomass energy through bamboos and bamboo grass (2). The reports of the Fuji Bamboo Garden, 51, 129-140.

Samuelsson, R., Thyrel, M., Sjöström, M., \& Lestander, T. A. (2009). Effect of biomaterial characteristics on pelletizing properties and biofuel pellet quality. Fuel Processing Technology, 90, 1129-1134. http://dx.doi.org/10.1016/j.fuproc.2009.05.007

Sato, K., Miyashita, T., Inakuma, T., Hayata, Y., \& Ikeura, H. (2012). Study of Pelletizing Tomato Stem and Leaf Waste and the Basic Combustion Characteristics of the Pellets. Journal of the Japan Society of Material Cycles and Waste Management, 23, 192-198. http://dx.doi.org/10.3985/jjsmcwm.1111002 
Takahashi, T., Tomita, K., \& Wakasugi, M. (2008). Effective utilization and evaluation of toxic substance for woody biomass combustion ash. Hokkaido industrial research report, 307, 59-67.

Tani, Y. (2009). The Available Utilization of the Paper Sludge Ash. Japan Tappi Journal, 63, 1465-1469. http://dx.doi.org/10.2524/jtappij.63.1465

Uchiyama, T., Hinoshita, M., \& Miyashita, S. (2001). Utilization of combustion ash of poultry manure in wet rice culture. Kinki Chugoku Agricultural Research, 102, 12-16.

Watanabe, K. (2010). Engeisakumotsu no Eiyosindan no Tebiki (pp. 28-29). Tokyo: Seibundosinkosha.

Woods, J., \& Mellon, M. (1941). Molybdenum Blue Reaction: A Spectrophotometric Study. Industrial \& Engineering Chemistry Analytical Edition, 13, 760-764. http://dx.doi.org/10.1021/i560099a003

\section{Copyrights}

Copyright for this article is retained by the author(s), with first publication rights granted to the journal.

This is an open-access article distributed under the terms and conditions of the Creative Commons Attribution license (http://creativecommons.org/licenses/by/3.0/). 